\title{
Study on the Development Planning of Ji'nan Airport Logistics Park
}

\author{
Shan-Shan WANG ${ }^{1, a}$, Kai DING ${ }^{2, b}$, Xiao-Xue REN ${ }^{1, c^{*}}$ \\ ${ }^{1}$ Shandong Jiaotong University, Ji'nan 250357, China \\ ${ }^{2}$ Dalian Maritime University, Dalian 116026, China \\ a851473725@qq.com, b787667959@qq.com, '1587351294@qq.com \\ *Xiao-Xue REN
}

Keywords: Airport logistics park, Facilities planning, Operation.

\begin{abstract}
With the rapid development of civil aviation and airport infrastructure, the airport logistics industry of China is in the initial stage of the strategy, its role in social and economic life is more and more important, and its development is a measure of the openness of China's market, the degree of economic development and make an important standard for the convenience of the material. The airport logistics park is an important part of modern logistics, and is the product of the effective combination of modern logistics and traditional air freight. Firstly, conception of development plan of Ji'nan Airport Logistics Park; secondly, in order to make the logistics park intensive function more powerful, more comprehensive, more to improve its service function and facilities planning; finally, This paper puts forward the design scheme of the development mode of Ji'nan airport logistics park, and puts forward the development mode of the airport logistics park.
\end{abstract}

\section{Introduction}

After decades of construction and development, China's civil aviation airport system has begun to take shape, and it formed in Beijing, Shanghai, Guangzhou and other hub airports as the center, taken Ji'nan, Chengdu, Kunming, Chongqing, Xi'an, Urumqi, Wuhan, Shenzhen, Shenyang, Hangzhou and other provincial capitals or key cities for the backbone of the backbone and the rest of the city. The basic pattern of cooperation with regional airports, rely on the airport, the airport in the vicinity of the construction of a number of airport logistics park, is also constantly emerging and development. With the arrival of the era of airport economy, we should seize this historic opportunity. On the basis of doing well in the research of market demand, with the advantage of the airport, vigorously develop modern logistics industry. Therefore, the development of Ji'nan airport logistics park is to meet the needs of social and economic development.

\section{Ji'nan Airport Logistics Park Development Plan}

\section{Ji'nan Airport Logistics Park Development Goal}

(1) Recent goals. According to the provisions of Ji'nan airport logistics park overall development plan , organize the zoning planning, infrastructure planning and land use planning, detailed planning control, port planning work, the basic completion of the Ji'nan Airport Logistics Park Development and construction. By the end of 2020, annual transport volume reached the target of Jinan Airport passenger throughput of 15 million passengers, cargo throughput of 133 thousand tons, becoming a regional hub airport in China developed fast. (2) Long term development goals. In the Ji'nan airport master plan, the airport's long-term goal is to 2040 passenger throughput of 47 million passengers per year, annual cargo throughput of up to 706 thousand tons, the aircraft took off and landing 407 thousand sorties. Airport logistics park has been completed, the infrastructure is perfect, ecological environment is good, the city has become an important economic growth plate, an important international aviation hub in East China, Ji'nan air logistics and airport industrial base. 


\section{The Function Orientation of Ji'nan Airport Logistics Park}

Relying on the Ji'nan airport, by air, express, air and road linking, waterway transport, international and domestic air cargo to provide high value-added logistics services, and actively develop air express and air freight business, vigorously develop the logistics service platform, such as aviation logistics service support platform, the key functions of the logistics platform, logistics platform for value-added features.

\section{Ji'nan Airport Logistics Park Service Functions and Facilities Planning}

\section{Airport Logistics Park Basic Function Planning of Ji'nan Airport Logistics Park}

Taking Ji'nan airport as the research object, the core is the airlines, air freight forwarders, integrated logistics enterprises, logistics facilities, commercial enterprises and logistics information. Airport logistics park operation framework figure is shown in figure 1.

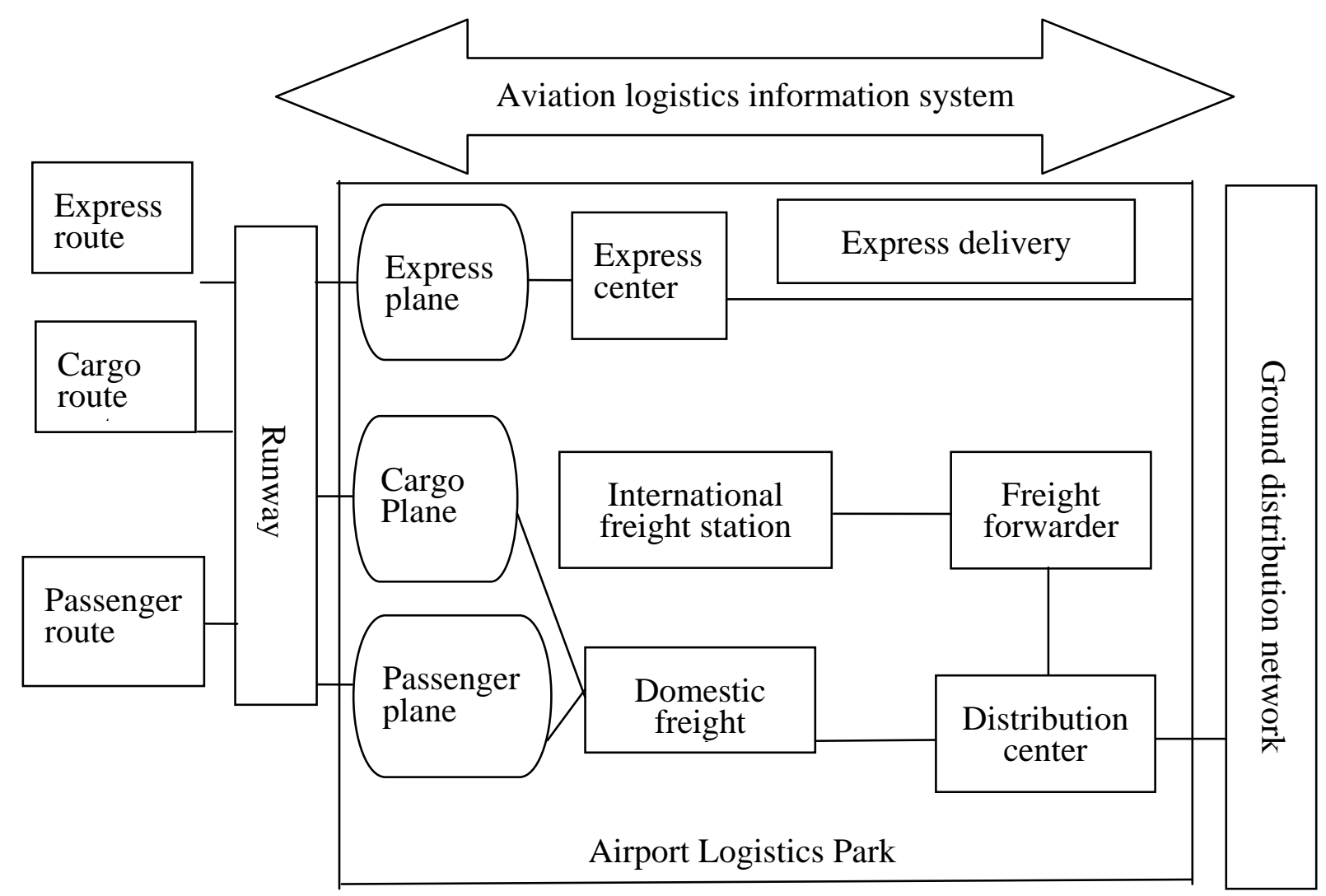

Fig.1 The operation of airport park logistics of the large framework hub

\section{Airport Logistics Park Facilities Planning}

Airport Logistics Park infrastructure including logistics service facilities, such as warehouse, yard, processing center; integrated logistics facilities logistics training, policy consulting, logistics services; service facilities, such as office buildings, restrooms, parking lot, maintenance center; living facilities, such as water, electricity accommodation, restaurant the bathroom, and sports fields. The airport logistics park is a subset of the logistics park, including not only public infrastructure in logistics park, but also including the freight station, freight village, air express transportation center, bonded logistics center and other major facilities. (1) Air cargo terminal. Airport air cargo transport infrastructure is an air cargo station, which is approved by the Civil Aviation Authority approved for air cargo storage, processing, circulation, transit sites. (2) Air cargo village. Air freight village in function to undertake the freight station, in the geographical location and the freight station is closely linked, is the airline, air freight forwarders to import and export cargo processing site.(3) Air express 
transshipment center. Air express transshipment hub is engaged in air express business infrastructure. (4) Bonded logistics center. Bonded logistics center is approved by the customs, by the Chinese enterprises to operate and engage in bonded warehousing logistics business of the centralized supervision of the local.

\section{Development and Operation of Ji'nan Airport Logistics Park}

\section{Development Mode of Ji'nan Airport Logistics Park}

The development mode of logistics park in China's is various, as economic development zone, the main business guide mode, the integrated use of industrial real estate business model. The domestic general logistics park development model has mode of economic development, the main business guide mode, business mode and operation mode of industrial real estate comprehensive development mode, they are the same suitable for different conditions of airport logistics park development and operation of aviation logistics park in Ji'nan is shown in Fig.2.

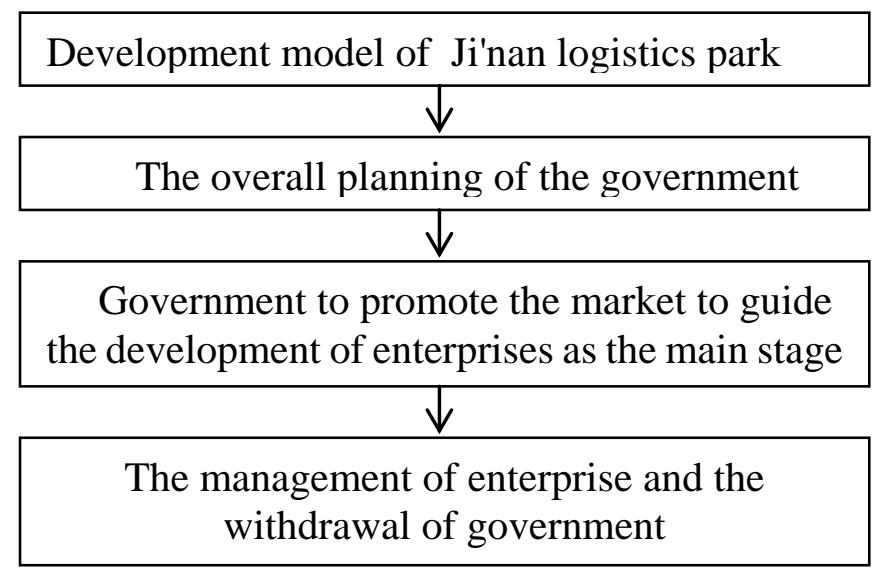

Fig. 2 The model Jinan Airport of Logistics development Park

\section{Airport Logistics Park Operation Mode Design}

Because of the complexity of the operation of the airport logistics park, in order to achieve the goal of the development and construction of the Ji'nan airport logistics park, the problems such as inaccurate positioning, low efficiency and poor returns are avoided. The implementation of standardized management of the Ji'nan airport logistics park is very necessary. By referring to the domestic and foreign successful logistics park operation and management experience, according to the idea of the overall development plan of Ji'nan airport logistics park, the use of existing resources, combined with the Ji'nan airport logistics park planning, design a business model of Ji'nan airport logistics park, management and operation mode and the profit model. According to the analysis of ideas, choose the operation mode according to the operation of capital ownership, participation, income risk and other indicators of the airport logistics park of different functional sections of the business analysis, the business model selection range. If the goods station business can have a range of operation of the joint venture in consideration, customs supervision warehouse and delivery center in the range of the land have to consider, ground services at the airport management and the specific operation mode is shown in Table 1. 
Table 1 Management project of Jinan airport logistics park

\begin{tabular}{|l|l|}
\hline Operation pattern & Operation mode characteristics \\
\hline Freight station service & $\begin{array}{l}\text { The best way to operate a station service is to manage the airport } \\
\text { independently or jointly with the airline }\end{array}$ \\
\hline $\begin{array}{l}\text { Ground service } \\
\text { operation mode }\end{array}$ & $\begin{array}{l}\text { The airport authority is responsible for coordinating the } \\
\text { development of the market, and then through a variety of ways to } \\
\text { manage and operate }\end{array}$ \\
\hline $\begin{array}{l}\text { Value added service } \\
\text { operation mode }\end{array}$ & $\begin{array}{l}\text { Airport authorities have no competitive advantage, then take the } \\
\text { franchise transfer management mode; if the airport has a strong } \\
\text { competitive advantage, can consider self or associates }\end{array}$ \\
\hline $\begin{array}{l}\text { Non air cargo logistics } \\
\text { business operation } \\
\text { mode }\end{array}$ & $\begin{array}{l}\text { Take the third party logistics service provider business model alone } \\
\text { or the Jinan airport authority and the third party logistics companies } \\
\text { could not participate in the operation of the business model }\end{array}$ \\
\hline
\end{tabular}

\section{Ji'nan Airport Logistics Park Development Mode}

Comprehensive comparison of different development mode of domestic airport logistics park and the existing successful experiences in the construction of airport logistics park, combined with the actual situation and the surrounding Jinan Airport, Ji'nan airport logistics park development mode should adopt the "government capital airport holding party participation, leading, large-scale logistics enterprises or logistics real estate franchise" mode, namely: "Shandong Province Airport Management Department of Ji'nan municipal government + large logistics company or logistics real estate joint venture + the airport holding form" Ji'nan airport logistics park development company operation, unified the overall development of Ji'nan airport logistics park.

\section{Summary}

In the reference and comparison of different airport logistics park development mode, starting from the actual combination of regional logistics demand and the construction of the airport logistics park and will support efforts to select or innovation to meet the actual needs of development. However, it is not involved in the airport, the airport is the core elements of pre conditions for construction of airport the logistics park must rely on, so the construction of the airport logistics park must be connected with the airport expansion development plan, and as far as possible to get the airport's strong support in the relevant aspects of the relationship, to form a stable development. As long run, Ji'nan airport logistics park, the government injection of ginseng and, the airport holding leading large-scale logistics enterprises or logistics real estate join cooperation development mode, can give full play to the local government, the airport, the different role of social enterprises and other parties involved in or related parties, and promote the rapid start and development of Ji'nan airport logistics park construction. In the construction of Ji'nan airport logistics park, adhere to the guiding ideology of Scientific Outlook on Development, green development, in order to improve the level of economic development, optimize the industrial structure, promote regional coordinated development as the goal, making full use of geographical advantages, Ji'nan science and technology education, the advantages of talents and industry resources, follow the "key industries, supporting industrial cooperation, industrial chain development, development of significant cluster effect", strengthen government guidance and policy support, system integration of existing resources, optimize the structure of the logistics park, to improve the quality of industrial development . 


\section{References}

[1] Hong Z S, Ding L D. The analysis of planning elements and design practice of large airport logistics park -- a case study of Tianjin Airport International Logistics Park [J]. City Planning Journal , 2009, (04):46-52. (In Chinese)

[2] Gu Z, Xia N. Airport Logistics Park function block layout [J]. Economic Geography, 2008, 28(02): 283-285. (In Chinese)

[3] Huang J W, Zhang L, Hao Y. Evaluation of the development level of Airport Logistics Park [J]. Enterprise Economy, 2008, 10(01): 117-119. (In Chinese)

[4] Li K P, Wang X Q. The characteristics, problems and Countermeasures of the development of airport logistics in China [J]. City Observation, 2013, (02): 35-41. (In Chinese) 